\section{術前リンパ球一単球比は腹腔鏡下大腸切後感染 性合併症の予測因子である}

○松田 明久 ${ }^{1)}$ 、松本 智司 ${ }^{1)}$ 、櫻澤 信行 ${ }^{1)}$ 、川野 陽一 ${ }^{1)}$ 山初 和也 ${ }^{1)}$ 、関口 久美子 ${ }^{1)}$ 、安藤 文彦 ${ }^{1)}$ 、山田 岳史 ${ }^{2)}$ 、 宮下 正夫 ${ }^{1)}$ 、内田 英二 ${ }^{2)}$

1) 日本医科大学千葉北総病院外科 ·消化器外科

2) 日本医科大学消化器外科

【緒言】近年、systemic inflammation-based marker が様々な癌種における予後予測に有用であるこ とが報告されている。リンパ球－単球比 (lymphocyte-to-monocyte ratio：LMR）は比較的新しい マーカーであり、大腸癌患者の予後予測への可能性 が報告される一方、術後短期成績との関連を検討し た報告はない。今回、LMR が大腸癌に対する腹腔 鏡下大腸切除後の術後感染症の予測因子となるか検 討した。

【方法】 2014 年 1 月〜 2015 年 8 月まで当科で施行し た腹腔鏡下大腸癌手術 211 例を対象とした。術後感 染症は Clavien-dindo grade 2 以上の感染性合併症 と定義し、NLR、PLR、LMR を含む臨床病理学的 因子と術後感染症との関係を検討した。

【結果】術後感染症は $16.6 \%$ に認め、術後感染症な し（n=176）とあり（n=35）の 2 群に分けて検討 したところ、単変量解析で両群間に有意差を認めた のは、性別、BMI、喫煙、開腹移行、手術時間、輸 血、同時切除、血中アルブミン值、そして LMR の 各因子であった $(\mathrm{P}<0.05)$ 。 Neutrophil-to-lymphocyte ratio (NLR)、 platelet-to-lymphocyte ratio（PLR）は、術後感染症発生と関連がなかった。 多変量解析では、手術時間、喫煙とともに低 LMR が独立した術後感染症予測因子として抽出された （LMR：オッズ比 3.97、95\% CI 1.44-10.9、P=0.008）。 【結語】術前 LMR は腹腔鏡下大腸癌手術後の術後 感染症の予測因子として簡便で有用なバイオマー カーである。
義

○白畑敦、高坂 佳宏

横浜旭中央総合病院

【はじめに】好中球/リンパ球比（N/L 比）は一般 的に炎症反応・栄養状態の指標とされ多種の癌で生 存率や再発率の予後予測因子となりうることが報告 されてきている。今回、敗血症性 DIC における N/ L 比の意義について検討した。

【対象】 2014 年 1 月から 2015 年 12 月までに当科に て敗血症性 DIC に対して集中治療を行った 34 例を 対象とした。患者平均年齢は $77.4 \pm 12.3$ 歳、男性 20 例、女性 14 例、診断時の SOFA score の平均值 は $8.3 \pm 2.9 、$ DIC score の平均值は $4.7 \pm 0.9 、 90$ 日 生存率は $69.7 \%$ であった。原因疾患は下部消化管穿 孔 16 例、術後合併症 6 例、壊疽性胆囊炎 5 例、腸 閉塞 3 例、上部消化管穿孔 1 例、その他 3 例で 87.5\% に対して手術を施行していた。DIC 診断基準 は日本救急医学会急性期診断基準を用いて、併用治 療は rTM (100\%)、AT 製剂 (100\%)、PMX-DHP (43.7\%)、輸血（50\%）であった。方法）生存期間 が90日未満を対照群、90日以上を判別群とし ROC 曲線から N/L 比の cut off 值を算出し臨床病理 学的検討をした。

【結果】N/L 比の平均值は $14.8 \pm 16.9$ (1.1-88.5)であっ た。Cut off 值は 15.9 （感度 40.0\%、特異度 83.0\%、 尤度比 2.4、オッズ比 3.3、AUC0.59） と設定した。 $\mathrm{A}$ 群 $(\mathrm{N} / \mathrm{L}$ 比 $\geqq 15.9 、 \mathrm{n}=9)$ と $\mathrm{B}$ 群 $(\mathrm{N} / \mathrm{L}$ 比 $<15.9$ 、 $\mathrm{n}=25$ ）に群分けし臨床病理学的検討を行った。 群と B 群では DIC スコア $(\mathrm{p}=0.02)$ 、SOFA スコ ア $(\mathrm{p}=0.05)$ 、白血球数 $(/ \mathrm{dl}) \quad(\mathrm{p}=0.003)$ の 3 因 子で有意差を認めた。9 日生存率は $\mathrm{A}$ 群 $55.6 \%$ 、B 群 $79.8 \%$ でB 群の予後が良好であった（p=0.026、 LR test)。

【考察】N/L 比は敗血症 DIC 患者の急性期において 炎症・栄養マーカーとしてだけではなく重症度・治 療転帰の予測マーカーである可能性が示唆された。 
CS-3

\section{間接熱量計を用いた重症救急患者のエネルギー 消費量と生命予後との検討}

小島 将裕、清水 健太郎、小倉 裕司、嶋津 岳士 大阪大学医学部附属病院高度救命救急セン夕ー
CS-4

膵癌細胞におけるスフィンゴシン -1- リン酸産 生酵素の働きとその代謝動態制御の解析

$\bigcirc$ 中島 真人 ${ }^{1)}$ 、永橋 昌幸 ${ }^{1)}$ 、三浦 要平 ${ }^{1)}$ 、安藤 拓也 ${ }^{1)}$

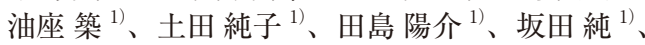
小林 隆 ${ }^{1)}$ 、亀山仁史 ${ }^{1)}$ 、阿部学 ${ }^{2)}$ 、崎村建司 ${ }^{2)}$ 、 若井 俊文 ${ }^{1)}$

1) 新潟大学大学院医歯学総合研究科消化器. 一般外科

2) 新潟大学脳研究所細胞神経生物学分野

【背景】癌細胞では、低酸素状態などの微小環境に 適応するため、糖代謝（Wargurg 効果）やアミノ 酸代謝などのリプログラミングが行われていること が知られている。一方、こうした癌細胞の代謝動態 の制御機構には未だに不明な点も多い。スフィンゴ シン -1 -リン酸（S1P）は、癌細胞の増殖や生存、 血管新生やリンパ管新生など、癌の進行に重要な機 能を制御する脂質メディエーターである。S1P は、 細胞内の 2 種類の S1P 産生酵素（SphK1、SphK2） によって産生され、細胞内外でその機能を発現する。 本研究において我々は、S1P ならびにS1P 産生酵 素が癌細胞の代謝動態の制御に関与し、その多彩な 機能を発現するという仮説を立て、膵癌細胞の S1P 産生酵素が代謝動態に与える影響を、メタボローム 解析によって解析した。

【方法】マウス由来膵癌細胞株である PAN02 細胞 に対して、CRISPR-Cas9 を用いて SphK1 をノック アウト（KO）した。WST-8 および Scratch アッセ イにより、SphK1 KO PAN02 細胞および野生型 （WT）細胞における増殖能および遊走能を解析した。 また、これらの細胞における代謝産物をキャピラ リー電気泳動質量分析法により定量し、メタボロー ム解析を行った。

【結果】通常の細胞培養下で SphK1 KO 細胞は、 WT 細胞と比較して細胞の増殖能が有意に上昇した。 SphK1 KO 細胞の遊走能も WT 細胞と比して有意 に上昇していた。しかし、抗癌剤 (Gemcitabine) 存在下において、SphK1 KO 細胞はWT 細胞と比 較して増殖能が有意に低下した。メタボローム解析 では、SphK1 KO 細胞において WT 細胞と比較し てアミノ酸合成や TCA 回路の代謝産物の低下、 ATP 産生の低下が認められた。また SphK1 KO 細 胞では、グルタチオン（GSH）について明らかな変 化を認めないものの、酸化ストレスに対する GSH の代謝産物である GSSG の低下を認め、SphK1 の 膵癌細胞における代謝動態への影響、ならびに特殊 な微小環境中での細胞生存や抗酸化能に対する関与 が示唆された。

【結論】我々の結果は、SphK1 を介した S1P 産生が 膵癌細胞の代謝動態の制御と多彩な細胞機能の発現 に重要な役割を果たしていることを示唆する。今後、 癌細胞に特徵的な代謝動態の制御の解明することが、 新規治療開発の礎になると期待される。 が必要である。 